\title{
Effects of Foreign Debt and Foreign Aid on Economic Growth in Somalia
}

\author{
Ali Yassin Sheikh Ali ${ }^{1}$, Mohamed Saney Dalmar ${ }^{2}$ \& Ali Abdulkadir Ali ${ }^{3}$ \\ ${ }^{1}$ Assistant Professor, Faculty of Economics, SIMAD University, Mogadishu, Somalia \\ ${ }^{2}$ Economist, Ministry of Finance, Federal Government of Somalia, Mogadishu, Somalia \\ ${ }^{3}$ Lecturer, Faculty of Humanities, Somali University, Mogadishu, Somalia \\ Correspondence: Ali Yassin, Faculty of Economics, SIMAD University, Somalia. Tel: 252-61-222-5577. E-mail: \\ profali@simad.edu.so
}

Received: September 20, 2018

Accepted: October 20, $2018 \quad$ Online Published: October 28, 2018

doi:10.5539/ijef.v10n11p95

URL: https://doi.org/10.5539/ijef.v10n11p95

\begin{abstract}
This paper aims to assess the effects of foreign debt and foreign aid on economic growth in Somalia from 1970 to 2014. The ordinary least squares (OLS) method was used and basic model assumption tests were also employed. We used the Augmented Dickey-Fuller (ADF) and Philip-Perron (PP) tests for the unit root and the Johansen cointegration test to determine the long-run relationship between the variables. The results of the study show that, in Somalia, foreign debt has an insignificant effect on economic growth, while the foreign aid has positive significant effect on economic growth. The results also indicate that the cointegration method confirms the incidence of long-run association among the variables. There is little research regarding the exact relationship between increasing foreign debt and foreign aid on economic growth in Somalia. This study is also different from previous studies as we used ADF and PP tests for the unit root and the Johansen cointegration test for the long-run relationship between the variables. Additionally, the study used multivariate techniques. The paper concludes that foreign aid is essential in economic growth and several policy implications are proposed.
\end{abstract}

Keywords: foreign debt, foreign aid, economic growth, Somalia

\section{Introduction}

To achieve long-term economic growth is the rational goal of any country but, for developing economies to achieve this goal, strategic decisions must be made to facilitate the desired levels of growth.

The 1950s and 1960s have been referred to as "golden years" for developing countries, when the least developed countries (LDCs) increased their investment with less dependence on external resources. However, in the 1970s, these countries began to rely more heavily on external investment, which also led to debt growth (Boboye, 2012). The external debt of developing countries like Somalia is, at least in part, due to borrowing from developed economies to improve the performance its industry, security, and agricultural sectors. Foreign borrowing for a country is especially required if the borrowed resources are used to fund economic development. Despite this, too much borrowing will lead an increase in the external debt, which will negatively affect the economy (Jilenga $\& \mathrm{Xu}, 2016)$.

Foreign aid is also known as official development assistance (ODA) and consists of the transfer of resources from developed to developing countries via concessional loans. There is an intense debate on the effect of foreign aid on the evolutionary processes of developing nations. Foreign aid is a significant topic, given its links to poverty reduction in developing countries. In Somalia, foreign aid has been increasing in recent years while foreign direct investment has been declining (Ekanayake \& Chatrna, 2014).

According to the economic literature, foreign debt can be defined as all the external obligations, due for repayment in over a year, that are unpaid at a particular point in time and are expected to be payable from reserve currency or via goods and services. Foreign aid is an international payment that contains of either a loan or a grant, from one country to another; these payments can either be multilateral, bilateral, or private assistance from a nongovernmental organization (Dritsakis et al., 2006). Somalia's external debt from 1980 to 2012 was approximately USD 5 billion; the amount of foreign debt increased drastically as a matter of survival and to fund development projects that would, in the long run, add to GDP (Todaro, 2009). 1993, 2009, and 2011 saw the 
greatest need for foreign aid in Somalia, caused by droughts.

Ilya (2017) investigated how Somalia could find the debt relief necessary for development. Somalia has been lent USD 5.1 billion by the international financial institutions, especially the International Monetary Fund (IMF) and, in the near future, there is hope that Somalia will begin to pay back this debt, based on established, well-planned, milestone-based guidelines regarding the debts and the standardization of relations with international financial institutions.

\section{Literature Review}

The study used a review of the literature to determine the most relevant explanatory and dependent variables as well as the most effective methods for analyzing the data.

\subsection{External Debt and Economic Growth}

Munzara (2015) examined the effects of foreign debt on economic growth in Zimbabwe. Annual data from 1980 to 2013 was used by employing ordinary least squares (OLS) regression. The results of the study indicated that foreign debt had a negative impact on economic growth of Zimbabwe. That the country should not be significantly dependent on foreign borrowing to finance economic growth was one of the major recommendations of the study. Onyango (2016) explored the impact of Kenya's foreign debt on its economic growth using annual data from 1975 to 2014. MS Office and SPSS version 20 were employed to analyze the data. The findings revealed that almost $37 \%$ of Kenya's GDP was influenced by the external debt. Conclusively, the paper showed that foreign debt had a positive impact on the economic growth of Kenya.

Umaru and Hamidu (2013) explored the link between foreign debt, domestic debt, and economic growth in Nigeria. The paper used yearly data from 1970 to 2010 and to analyze the simple relationship between the study variables using the OLS method. Different tests, such as Augmented Dickey-Fuller (ADF) and Granger causality were employed. The findings of the study showed that foreign debt had a negative impact on economic growth. Ijirshar et al. (2016) studied the connection between foreign debt and economic growth in Nigeria for the period from 1981 to 2014. ADF, Granger causality, and Johansen cointegration tests were employed. The results of the study indicated that only in the long run did foreign debt have a positive effect on the Nigerian economy.

Bhatta (2003) assessed the association among external debt and economic growth of Nepal. The results indicated that the foreign debt flow was having a positive influence on economic growth. This further emphasizes that foreign debt must not be considered merely as a burden but also as the main means of finance for a developing economy.

\subsection{Foreign Aid and Economic Growth}

Hossain (2014) studied the impact of foreign aid on economic growth in Bangladesh. Annual data from 1980 to 2012 were used. The outcomes of the study indicated that foreign aid had a positive impact on the economic growth of Bangladesh, although foreign aid delivered diminishing returns because of decreasing utilization of the aid. Similarly, Ugochukwu et al. (2016) examined the effect of foreign borrowing and foreign financial aid on the growth of Nigeria from 1980 to 2013. The study used the OLS multiple regression model to determine the causal effect among the variables, ADF to check the stationarity, and Johansen cointegration to test the long-run association. The findings revealed that foreign debt had a positive and significant influence on economic growth, while foreign aid had an expected effect on the economy, but statistically insignificant.

Boakye (2008) studied the long-run aid-effectiveness for per-capita economic growth in the Philippines by using time series data from 1970 to 2010. The study used the vector error correction model (VECM) approach to cointegration analysis. The results of the study indicated that the influence of foreign aid on economic growth would be subject to how aid was used for development projects in the Philippines. A study by Durbarry et al. (1998) assessed the influence of foreign aid on economic growth for a large sample of emerging economies. The study used an augmented Fischer-Easterly-type model and estimated this by employing both cross-section and panel-data techniques. Findings strongly supported the opinion that external aid does have a positive influence on the economic growth when the macroeconomic policy environment is conditionally stable.

Appiah-Konadu et al. (2016) examined the association between foreign aid and economic growth in Ghana from 1972 to 2012. The autoregressive distributed lag (ARDL) method was used for cointegration checking to observe both the long-run and short-run connections between foreign aid and economic growth. ARDL bounds testing indicated that there was a cointegrating equation between foreign aid and economic growth in Ghana. From the findings, foreign aid and interest payment on foreign debt was found to have a negative influence on the economic growth in Ghana. In Sudan, Mustafa et al. (2018) investigated the association between foreign aid and economic growth by using yearly data from1980 to 2015. ARDL bounds testing for co-integration was employed. 
Results revealed a positive relationship between the variables.

\section{Methods and Methodology}

\subsection{Data Type and Source}

This research made use of secondary data for the period from 1970 to 2014 to analyze the model of the study. The main sources of these data were the World Bank Group and World Development Indicators. There is little research regarding the exact relationship between increasing foreign debt and foreign aid on economic growth in Somalia. This study is also different from previous studies as we tested unit root using ADF and Philip-Perron (PP) tests and employed the Johansen cointegration technique and VECM. Additionally, the study used multivariate techniques.

\subsection{Model Development}

The model that we utilized in the empirical investigation is time-series based to demonstrate the effects of foreign debt and aid on economic growth, articulated as follows:

$$
G D P=F(E D, F A)
$$

where GDP is economic growth, $\mathrm{F}$ is a function of economic growth, ED is external debt, and FA is foreign aid. This typical model can be expressed in direct form as follows:

$$
Y=\beta 1+\beta 2 E D+\beta 3 F A+U
$$

where: $\mathrm{Y}$ denotes economic growth; ED denotes external debt; FA denotes foreign aid; $\beta 1, \beta 2$, and $\beta 3$ denote the slope of the regression equation; and $\mathrm{U}$ denotes the stochastic error term.

\section{Data Analysis}

\subsection{Trend Analysis}

The study used data from the World Bank, using GDP is the proxy for economic growth (Figure 1). The GDP of the country has increased in the last two decades, with a huge increase in GDP from 1986 to 1990. As previously explained, based on prior economic studies, we define external debt as all external duties with a maturity of one year or more that are unpaid at a particular point in time and are payable in terms of reserve currency or goods and services. Somalia has borrowed money from external sources, now more than USD 5 billion (Figure 2) and this has led to the IMF to announce that Somalia cannot borrow any more until the equivalent amount of debt has been repaid. Somalia has also received a lot of money from international foreign aid, or ODA (Figure 3), with the aim of making the economy recover from its stagnated state.

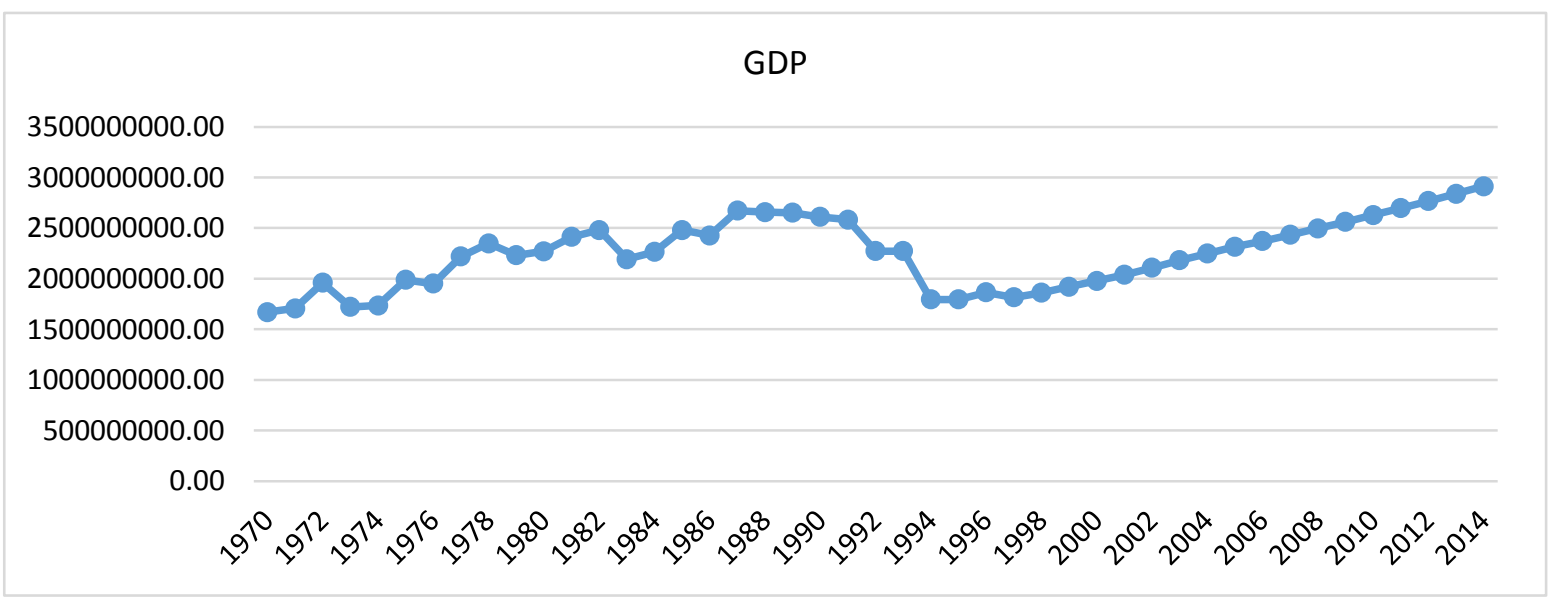

Figure 1. Somalia's GDP (1970-2014) 


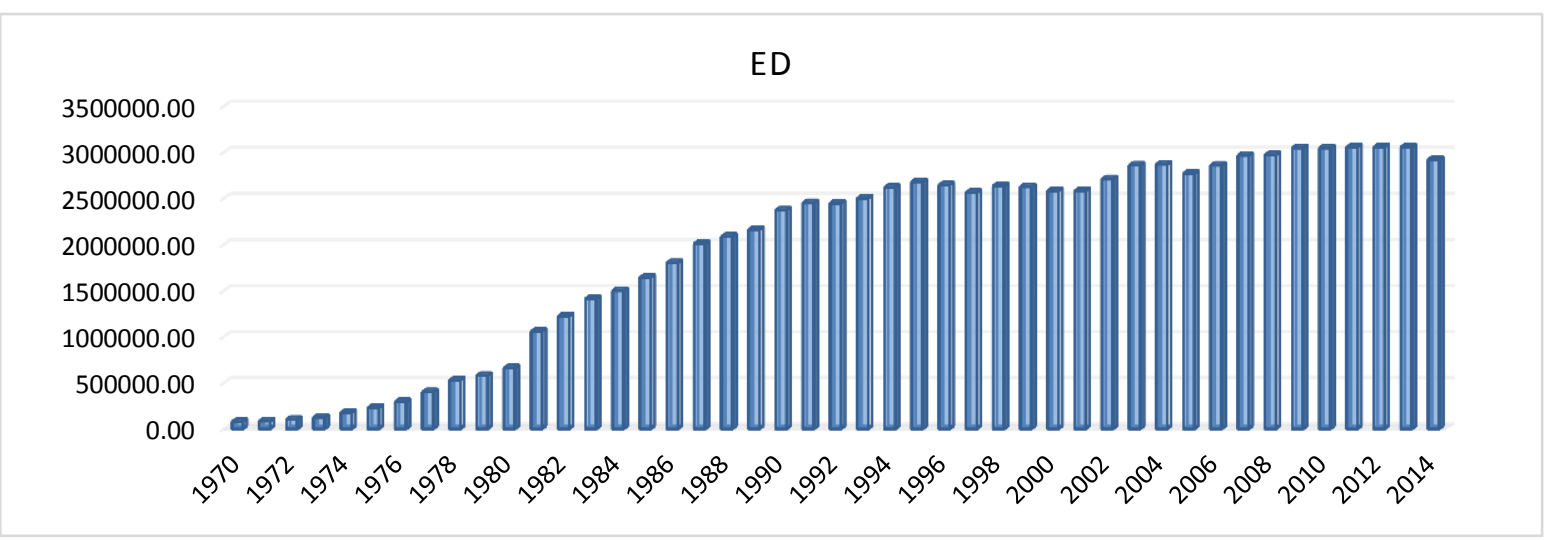

Figure 2. Somalia's external debt (1970-2014)

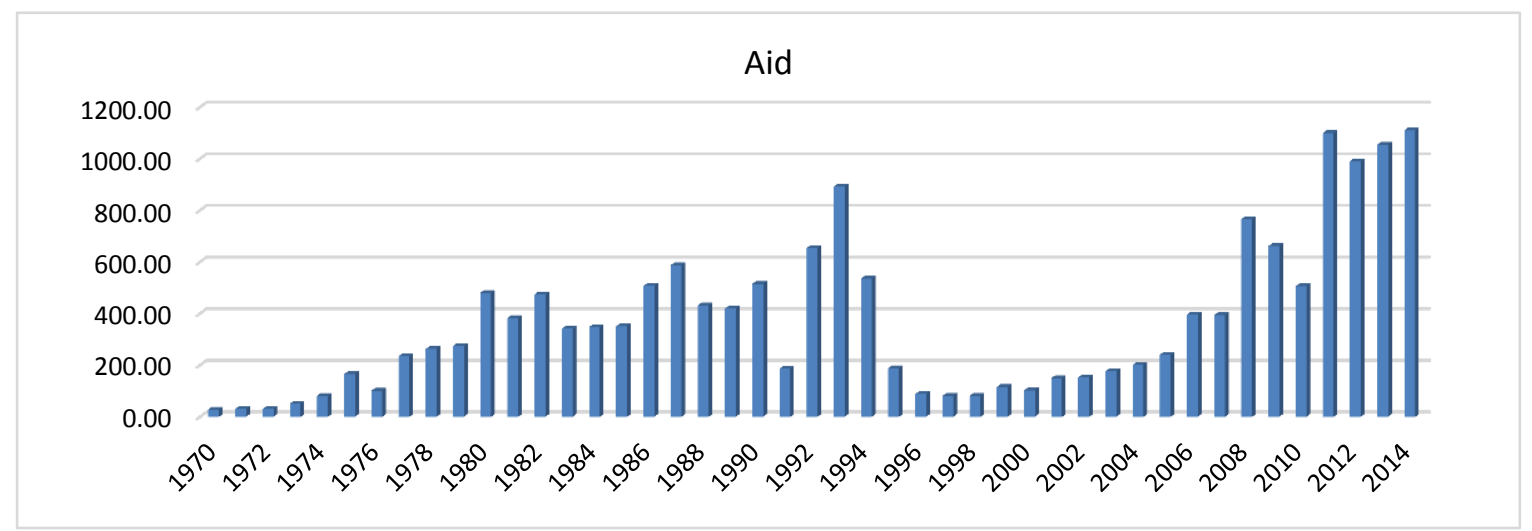

Figure 3. Somalia's foreign aid (1970-2014)

\subsection{Regression Results}

The regression results for GDP, ED (external debt), and AID (foreign aid) in the Somali economy from 1970 to 2014 are presented in Table I. The value of the adjusted $R^{2}$ is a good indicator for reliable data: adjusted $R^{2}$ value is 0.6853 , or $68.53 \%$, confirming that the model is robust; the adjusted $R^{2}$ value indicated that roughly $68.53 \%$ of variation in the dependent variable (economic growth/GDP) was explained by the independent variables (ED and AID) in this model.

Table 1. Ordinary least Squares (OLS) regression

\begin{tabular}{|c|c|c|c|c|c|c|}
\hline Source & SS & df & MS & Number of obs. & $=45$ & \\
\hline Model & 0.730915969 & 2 & 0.365457985 & $\mathrm{~F}(2,42)$ & $=48.91$ & \\
\hline \multirow[t]{2}{*}{ Residual } & 0.313847957 & 42 & 0.00747257 & Prob $>F$ & $=0.0000$ & \\
\hline & & & & R-squared & $=0.6996$ & \\
\hline \multirow[t]{2}{*}{ Total } & 1.04476393 & 44 & 0.023744635 & Adj R-squared & $=0.6853$ & \\
\hline & & & & Root MSE & $=0.08644$ & \\
\hline $\log \mathrm{GDP}$ & Coef. & Std. Err. & $\mathrm{t}$ & $\mathrm{P}>\mathrm{t}$ & [95\% Conf. & Interval] \\
\hline $\log E D$ & -0.000592 & 0.0152977 & -0.04 & 0.969 & -0.031464 & 0.0302801 \\
\hline $\log$ AID & 0.131264 & 0.017371 & 7.56 & 0.000 & 0.096208 & 0.16632 \\
\hline _Cons & 20.80494 & 0.1705207 & 122.01 & 0.000 & 20.46081 & 21.14906 \\
\hline
\end{tabular}

The overall significance of the model using F-statistics indicated that the regression model was good. Additionally, the paper tested the single statistical significance of the coefficients. Remarkably, one of the factors, AID, was statistically significant at the $5 \%$ level. This implies that AID is statistically significant and affects the GDP positively; which means that, as AID increases, GDP also increases. The other coefficient, however, was statistically insignificant. 


\subsection{Model Diagnostic Tests}

The classical linear regression model was used to test residual normality. The residues tracked a normal distribution, as our model shows (Figure 4). Normality was confirmed since the p-value was greater than the significance level of 5\% while the Jarque-Bera normality test score was 1.058 .

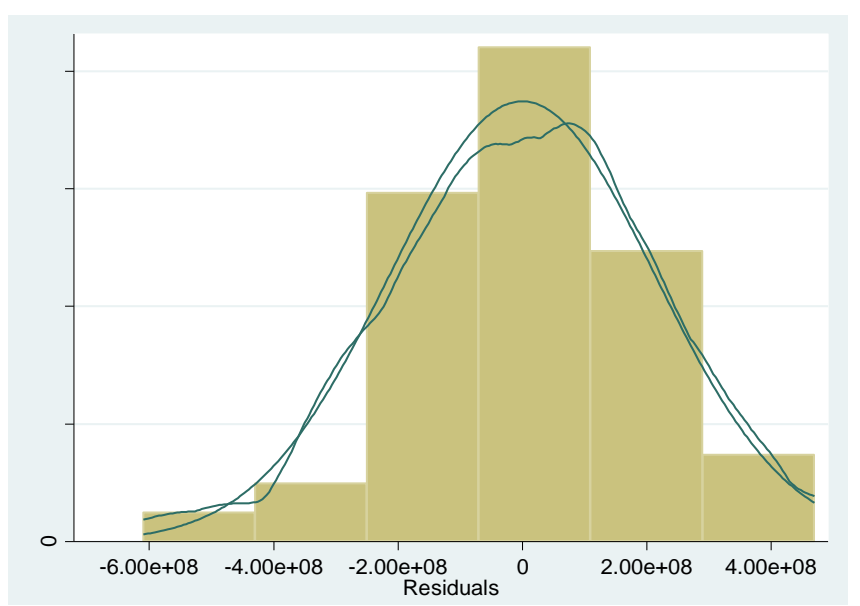

Figure 4. Jarque-Bera normality test

Note. Jarque-Bera test for H0: normality. Jarque-Bera normality test: 1.058 (chi-square $=0.5891$ ).

Again, the study tested for autocorrelation. Results of this test showed that the errors were serially correlated while the p-value was less than the $\mathrm{Obs}^{*} \mathrm{R}^{2}$ (Table 2). Finally, we checked the Breusch-Pagan for Heteroscedasticity and found that there is a lack of heteroscedasticity in the model as the p-value is greater than the Obs* $\mathrm{R}^{2}$ (Table 3).

Table 2. Breusch-Godfrey LM test for serial correlation.

\begin{tabular}{l|lll}
\hline $\operatorname{lags}(\mathrm{p})$ & $\mathrm{chi}^{2}$ & $\mathrm{df}$ & Prob $>$ chi $^{2}$ \\
\hline 1 & 17.995 & 1 & 0.0000 \\
\hline
\end{tabular}

Note. H0: no serial correlation.

Table 3. Breusch-Pagan test for heteroscedasticity

\begin{tabular}{ll}
\hline H0: Constant variance & \\
Variables: fitted values of GDP & \\
\hline $\operatorname{chi}^{2}(1)=0.29$ & Prob $>\operatorname{chi}^{2}=0.5929$ \\
\hline
\end{tabular}

\subsection{Correlation Analysis}

The results in Table 4 confirm that there was a strong positive association between GDP and AID. There was a weak positive association between GDP and ED. Table 4 also reveals that there was a moderate relationship between AID and ED. Finally, Table 4 shows that the correlation among all the variables was positive and significant.

Table 4. Pairwise correlation and significance test

\begin{tabular}{llrr}
\hline & GDP & ED & AID \\
\hline GDP & 1.0000 & & \\
ED & $0.4435^{*}$ & 1.0000 & \\
& 0.0023 & & 1.0000 \\
AID & $0.7748^{*}$ & $0.4750^{*}$ & \\
& 0.0000 & 0.0010 & \\
\hline
\end{tabular}

Note. $\mathrm{GDP}=$ gross domestic product; $\mathrm{ED}=$ external debt; $\mathrm{AID}=$ foreign aid. 


\subsection{Unit Root Test}

In order to analyze the time series characteristic, we employed the ADF and PP tests to check the unit root in time-series data. We tested this by using two equations included in ADF and PP tests to test the variables with intercept only and intercept with trend (Table 5). By doing so, we can confirm that our all variables were non-stationary at their level. However, when we performed the tests for the first difference of the data, all variables were stationary with intercept only and intercept with trend.

Table 5. ADF and PP tests to check the unit root in time series data

\begin{tabular}{lcccc}
\hline \multicolumn{2}{c}{ ADF } & \multicolumn{2}{c}{ PP } \\
\hline Variables & Intercept only & Intercept with trend & Intercept only & Intercept with trend \\
\hline Level & & & & -1.701 \\
GDP & -1.285 & -1.497 & -1.455 & -1.940 \\
FA & -1.433 & -2.018 & -1.236 & 0.064 \\
ED & -2.344 & 0.471 & -1.978 & $-6.744^{* * *}$ \\
$\mathbf{1}^{\text {st }}$ Difference & & & & $-6.744^{* * *}$ \\
$\Delta$ GDP & $-6.805^{* * *}$ & $-6.724^{* * *}$ & $-6.817^{* * *}$ & $-6.744^{* * * *}$ \\
$\Delta$ FA & $-7.695^{* * *}$ & $-7.671^{* * *}$ & $-6.817^{* * *}$ & $-6.817^{* * *}$ \\
$\Delta$ ED & $-3.813^{* * *}$ & $-4.516^{* * *}$ & & \\
\hline
\end{tabular}

Note. $* * * p<0.001$.

\subsection{Lag Length Criteria}

Once we had tested the unit root, we proceeded to test the supreme lag length of the model via vector autoregression (VAR) lag order selection criteria. The results of this test are available in Table 6 and reveal that the maximum lag length of the model is "1," selected on the basis of the minimum value of each criterion, including final prediction error (FPE), Akaike information criterion (AIC), Hannan-Quinn information criterion (HQIC), and Bayesian information criterion (SBIC).

Table 6. Lag selection-order criteria

\begin{tabular}{|c|c|c|c|c|c|c|c|c|c|}
\hline Lag & & LL & LR & $\mathrm{df}$ & $\mathrm{p}$ & FPE & AIC & HQIC & SBIC \\
\hline 0 & - & 1753.26 & & & & $3.2 \mathrm{e}+33$ & 85.6711 & 85.7168 & 85.7965 \\
\hline 1 & - & 1609.29 & 287.94 & 9 & 0.000 & $4.5 \mathrm{e}+30^{*}$ & $79.0873 *$ & $79.2699 *$ & $79.5888^{*}$ \\
\hline 2 & - & 1602.41 & 13.755 & 9 & 0.131 & $5.0 \mathrm{e}+30$ & 79.1908 & 79.5104 & 80.0685 \\
\hline 3 & - & 1596.74 & 11.353 & 9 & 0.252 & $6.0 \mathrm{e}+30$ & 79.3529 & 79.8095 & 80.6068 \\
\hline 4 & - & 1588.06 & $17.354 *$ & 9 & 0.043 & $6.3 e+30$ & 79.3687 & 79.9622 & 80.9987 \\
\hline
\end{tabular}

Note. Endogenous: GDP, ED, AID. Exogenous:_cons. Sample: 1974-2014. Number of obs. $=41$.

\subsection{Granger Causality}

The pairwise Granger causality test indicated that there was no unidirectional or bidirectional causality between GDP and ED or AID and ED (Table 7). Finally, results indicated that there was unidirectional causality between AID and GDP, but not bidirectional causality.

Table 7. Wald-Granger causality test

\begin{tabular}{llcc}
\hline Null hypothesis & Obs. & F-statistic & Prob. \\
\hline GDP does not Granger cause ED & 44 & 0.00681 & 0.934 \\
ED does not Granger cause GDP & & 2.2677 & 0.132 \\
AID does not Granger cause ED & 44 & 0.28216 & 0.595 \\
ED does not Granger cause AID & & 0.00651 & 0.936 \\
AID does not Granger cause GDP & 44 & 12.637 & 0.000 \\
GDP does not Granger cause AID & & 0.00021 & 0.988 \\
\hline
\end{tabular}

\subsection{Johansson Test of Cointegration}

The results of this test in Table 8 reveal that the null hypothesis of no cointegration $(r=0)$ on both trace test and 
maximum eigenvalue check among ED, FA, and GDP can be rejected at 5\%; however, the null hypothesis of no cointegration $(r \leq 1)$ could not be rejected at $5 \%$, suggesting that there is only one cointegration vector.

Table 8. Johansen tests for cointegration

\begin{tabular}{|c|c|c|c|c|c|}
\hline \multicolumn{2}{|c|}{ Maximum } & \multirow[b]{2}{*}{ LL } & \multirow[b]{2}{*}{ eigenvalue } & \multirow[b]{2}{*}{ trace statistic } & \multirow[b]{2}{*}{ critical value } \\
\hline rank & parms & & & & \\
\hline 0 & 3 & -1742.443 & & $28.5682 *$ & 29.68 \\
\hline 1 & 8 & -1732.9521 & 0.35040 & 9.5865 & 15.41 \\
\hline 2 & 11 & -1728.8862 & 0.16874 & 1.4546 & 3.76 \\
\hline 3 & 12 & -1728.1589 & 0.03252 & & \\
\hline \multicolumn{2}{|c|}{ Maximum } & & & & $5 \%$ \\
\hline rank & parms & LL & eigenvalue & max statistic & critical value \\
\hline 0 & 3 & -1742.443 & & 18.9817 & 20.97 \\
\hline 1 & 8 & -1732.9521 & 0.35040 & 8.1318 & 14.07 \\
\hline 2 & 11 & -1728.8862 & 0.16874 & 1.4546 & 3.76 \\
\hline 3 & 12 & -1728.1589 & 0.03252 & & \\
\hline
\end{tabular}

Note. Trend: constant. Number of obs. $=44$. Sample: $1971-2014$. Lags $=1$.

\section{Conclusion}

This paper has provided results for regression analysis of the effects of foreign debt and foreign aid on the growth of the Somali economy from 1970 to 2014. The aim of the study was to establish whether there exist short-run and long-run relationships between the independent variables and economic growth. The adjusted $\mathrm{R}^{2}$ of the model was $68.53 \%$, which indicates that the model fit the data well; the total variation in the witnessed GDP behavior was impacted both by the disparities in foreign debt and foreign aid. The outstanding $31.47 \%$ can be accounted for by the error term.

To trial the general significance of the model, the F-statistic was utilized. The t-statistics of the corresponding variables were carefully measured when assessing the individual statistical significance of the parameters. Based on their probability values, the study showed that foreign aid is significant. However, external debt has an insignificant effect on the economy.

The significance of external debt and foreign aid for economic growth has been well documented in the literature as both of these indicators play a significant role in the overall performance of the economy. However, while most of the literature has found that both external debt and foreign aid have a significant impact on economic growth, the findings of this study reveal a significant impact for aid but not for debt. Previous studies have found that aid and economic growth has positive relationships, in line with the results of this study (Appiah-Konadu et al., 2016; Mustafa et al., 2018). However, there are many studies that have found a negative association between external debt and economic growth.

All the models we used in this study conclusively indicated that foreign aid had a positive effect on the economic growth of Somalia. It must be noted, however, that the institutions in Somalia responsible for receiving and distributing aid, including public administration, have capacity restraints, primarily because of poor organization and planning, corruption, injustice, and political instability. Based on the results of our study, the following policy implications are proposed: foreign debts should be used exclusively for economic causes, not for political objectives; the authorities must effectively track debt-repayment obligations to avoid "debt overhang;" managing institutions should be aware of the level of debt and not to allow it to pass its maximum limit; and the volatility and unpredictability of aid inflow, which might possibly cause difficulties regarding the fiscal balance, must be taken into consideration and planned for.

\section{References}

Appiah-Konadu, P., Junior, F. S., Eric, A., \& Twerefou, D. K. (2016). The effect of foreign aid on economic growth in Ghana. African Journal of Economic Review, 4(2), 248-261.

Bhatta, G. (2003). An assessment of the impact of external debt on economic growth of Nepal. Economic Review: Occasional Paper. Retrieved from http://www.nrb.org.np/ecorev/pdffiles/vol15_art6.pdf

Boakye, P. F. (2008). Foreign aid and economic growth in Ghana (1970-2005). Master's thesis, Department of Economics, Kwame Nkrumah University of Science and Technology. Retrieved from http://www.ir.knust.edu.gh/bitstream/123456789/607/1/PRINCE\%20FRIMPONG\%20BOAKYE.pdf 
Boboye, A. L. (2012). Effect of external debt on economic growth and development of Nigeria. International Journal of Business and Social Science, 3(12), 297-304.

Dritsakis, N. V., Varelas, E., \& Adamopoulos, A. (2006). The main determinants of economic growth: An empirical investigation with Granger causality analysis for Greece. European Research Studies Journal, IX(3/4), 47-58.

Durbarry, R., Gemmell, N., \& Greenaway, D. (1998). New evidence on the impact of foreign aid on economic growth. CREDIT Research Paper 98. Retrieved from http://www.sherpa.ac.uk/credit/documents/papers/98-08.pdf

Ekanayake, E. M., \& Chatrna, D. (2014). The effect of foreign aid on economic growth in developing countries. Journal of International Business and Cultural Studies, 3, 1-13.

Hossain, B. (2014). The effect of foreign aid on the economic growth of Bangladesh. Journal of Economics and Development Studies, 2(2), 93-105.

Ijirshar, V. U., Joseph, F., \& Godoo, M. (2016). The relationship between external debt and economic growth in Nigeria. International Journal of Economics \& Management Sciences, 6(1), 1-5. https://doi.org/10.4172/2162-6359.1000390

Ilya, G. (2017). Can Somalia find the debt relief necessary for development? IPI Global Observatory. Retrieved from http://www.theglobalobservatory.org/2017/07/somalia-development-debt-london-conference/

Jilenga, M. T., \& Xu, H. (2016). The impact of external debt and foreign direct investment on economic growth : Empirical evidence from Tanzania. International Journal of Financial Research, 7(2), 154-162. https://doi.org/10.5430/ijfr.v7n2p154

Munzara, A. T. (2015). Impact of foreign debt on economic growth in Zimbabwe. IOSR Journal of Economics and Finance, 6(5), 87-91.

Mustafa, M. E., Elshakh, M. M., \& Ebaidalla, E. M. (2018). Does foreign aid promote economic growth in sudan? Evidence from ARDL Bounds Testing Analysis. Paper presented at The Economic Research Forum's (ERF) 24th Annual Conference. Retrieved from http://www.erf.org.eg/wp-content/uploads/2018/02/4-23-Mahjoub-Ebaidallah.pdf

Onyango, B. (2016). Effect of foreign debt on economic growth in Kenya. Master's thesis, School of Business, University of Nairobi. Retrieved from http://www.erepository.uonbi.ac.ke/bitstream/handle/11295/99453/Onyango_Effect\%20Of\%20Foreign\%20 Debt\%200n\%20Economic\%20Growth\%20In\%20Kenya.pdf?sequence=1\&isAllowed=y

Todaro, M. P. (2009). Economic Development (10th ed.). New York, NY: Addison-Wesley.

Ugochukwu, U. S., Okafor, I., \& Azino, A. C. (2016). Effect of external borrowing and foreign aid on economic growth in Nigeria. International Journal of Academic Research in Business and Social Sciences, 6(4), 155-175. https://doi.org/10.6007/IJARBSS/v6-i4/2087

Umaru, A., \& Hamidu, A. A. (2013). External debt and domestic debt impact on the growth of the Nigerian economy. International Journal of Educational Research, 1(2), 70-85.

\section{Copyrights}

Copyright for this article is retained by the author(s), with first publication rights granted to the journal.

This is an open-access article distributed under the terms and conditions of the Creative Commons Attribution license (http://creativecommons.org/licenses/by/4.0/). 